\title{
Fall grazing affects big game forage on rough fescue grasslands
}

\author{
JEFFREY J. SHORT AND JAMES E. KNIGHT
}

Authors are Graduate Sudent and Extension Wildlife Specialist, Department of Animal and Range Sciences, Montana State University, Bozeman, Mont. 59717.

Abstract

Prescribed cattle grazing is often used to purposely enhance wildlife habitat. This study investigated the effects of fall cattle (Bos taurus) grazing intensity on elk (Cervus elaphus) and deer (Odocoileus spp.) forage in the following spring and summer. These effects were examined on rough fescue (Festuca scabrella Torr.) range on the Blackfoot Clearwater Wildlife Management Area in west central Montana. Cattle were grazed in enclosures during the fall of 1997 and 1998. A randomized complete block design with 5 replications of enclosures per year was used. Grazing levels were $0 \%$ removal (control), $50 \%$ removal, $70 \%$ removal, and $90 \%$ removal of herbaceous standing crop. To evaluate elk and deer forage, measurements were obtained in spring and summer on green grass standing crop, green forb standing crop, percent green vegetation, species richness, and plant species composition. There were no differences among grazing levels for plant species composition based on canopy coverage,

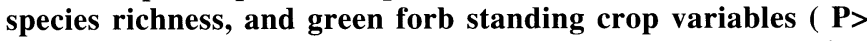
0.10). The $50 \%$ and $90 \%$ treatments reduced green standing crop in spring $(P=0.07)$ but not in summer $(P>0.10)$. Grazing treatments increased percent green vegetation $(P<0.01)$. Fall cattle grazing can be used as a wildlife habitat improvement tool to reduce unpalatable standing dead material. The $70 \%$ removal treatment was the most favorable for habitat improvement without degrading the range.

Key Words: Cervus elaphus, Festuca scabrella, Odocoileus spp., livestock-wildlife relations, prescribed livestock grazing

The compatibility of livestock and wildlife on western ranges has been discussed often (Anderson and Scherzinger 1975). Managers traditionally considered livestock activities in wildlife habitat to be detrimental, which led to removal of domestic livestock from many lands managed for wildlife (Jourdonnais and Bedunah 1985). Competition between cattle (Bos taurus) and deer (Odocoileus spp.) or elk (Cervus elaphus) is less than once thought (Kingery et al. 1996, Vavra and Sheehy 1996). Previous research has revealed that wild cervids, such as deer and elk, are more selective herbivores than cattle (McMahan 1964, Collins et al. 1978, Kingery et al. 1996). Positive aspects of livestock grazing on wildlife habitat should be addressed. Livestock producers and wildlife managers benefit from this information.

The authors wish to express thanks to the Montana Department of Fish, Wildlife and Parks for their cooperation and assistance in the completion of this project. Research was funded in part by the Montana Agricultural Experiment Station.

Manuscript accepted 13 Jun. 02.

\section{Resumen}

El apacentamiento prescrito del ganado a menudo es usado con el propósito de mejorar el hábitat de la fauna silvestre. En este estudio se investigaron los efectos de la intensidad de apacentamiento en otoño del ganado (Bos taurus) en el forraje disponible para alces (Cervus elaphus) y venados (Odocoileus spp.) en la siguiente primavera y verano. Estos efectos se examinaron en un pastizal de "Rough fescue" (Festuca scabrella Torr.) en el área de Manejo de Fauna Silvestre "Blackfoot Clearwater" localizado en la región central oeste de Montana. El ganado apacentó en exclusiones durante el otoño de 1997 y 1998. Se uso un diseño de bloques completos al azar con 5 repeticiones de exclusión por año. Los niveles de apacentamiento fueron $0 \%$ (control), $50 \%, 70 \%$, y $90 \%$ de remoción de la biomasa en pie. Para evaluar el forraje para el alce y el venado se obtuvieron mediciones en primavera y verano de la biomasa verde en pie de zacates y hierbas, porcentaje de vegetación verde, riqueza de especies y composición de especies vegetales. Los niveles de apacentamiento no mostraron diferencias en la composición de especies de plantas, basado en la cobertura de copa, en la riqueza de especies de plantas y biomasa verde en pie de hierbas $(P>$ 0.10). Los tratamientos de $50 \%$ y $90 \%$ redujeron la biomasa verde en pie en primavera $(P=0.07)$, pero no en verano $(P>$ 0.10). Los tratamientos de apacentamiento incrementaron el porcentaje de vegetación verde $(P<0.01)$. El apacentamiento del ganado en otoño puede ser usado como una herramienta de mejoramiento del hábitat de la fauna silvestre para reducir la biomasa muerta no apetecible. El tratamiento de $70 \%$ de remoción fue el mas favorable para mejorar hábitat sin degradar el pastizal.

Several studies have examined the effects of cattle grazing on winter forage for deer and elk (Anderson and Scherzinger 1975, Neal 1982, Urness 1982, Vavra and Sheehy 1996, Wambolt et al. 1997, Clark et al. 1998). However, there has been little research on how cattle grazing affects spring and summer forage. Spring and summer range is very important for deer and elk production (Collins et al. 1978).

Deer and elk select green grass during spring (Jourdonnais and Bedunah 1985, Lyon 1985). In summer, deer and elk diets consist largely of forbs (McMahan 1964, Stevens 1966, Collins et al. 1978, Kasworm et al. 1984, Jourdonnais and Bedunah 1985, Lyon 1985, Canon et al. 1987, Kingery et al. 1996). Collins et al. (1978) stated that species diversity is an important aspect of wildlife forage. Unpalatable standing dead material is considered a barrier to grazing in bunchgrasses (Willms and McLean 1978, Willms et al. 1979, 1980, 1981, Ruyle et al. 1987, Provenza and 
Table 1. Mean relative utilization and stubble height $( \pm \mathrm{SD})$ of herbaceous standing crop in treated plots. Utilization expressed as percent removed of current standing crop.

\begin{tabular}{lccc}
\hline \hline Year & Target Treatment & Actual Utilization & Stubble Height \\
\hline \multirow{3}{*}{1997} & & $(\%)$ & $(\mathrm{cm})$ \\
& $50 \%$ & $48.9 \pm 2.5$ & $22.2 \pm 3.3$ \\
& $70 \%$ & $70.6 \pm 3.4$ & $11.0 \pm 2.2$ \\
1998 & $90 \%$ & $88.0 \pm 1.4$ & $5.2 \pm 1.6$ \\
& $50 \%$ & $49.4 \pm 2.6$ & $21.5 \pm 3.1$ \\
& $70 \%$ & $69.3 \pm 1.0$ & $12.6 \pm 2.1$ \\
Average & $90 \%$ & $89.2 \pm 1.4$ & $4.0 \pm 1.9$ \\
& $50 \%$ & $49.2 \pm 2.4$ & $21.9 \pm 3.2$ \\
& $70 \%$ & $70.0 \pm 2.4$ & $11.8 \pm 2.3$ \\
& $90 \%$ & $88.6 \pm 1.5$ & $4.6 \pm 2.0$ \\
\hline
\end{tabular}

Balph 1990). When managing spring and summer range, it is important to consider that deer and elk select green grass during spring, forbs during summer, and avoid plants with standing dead material present.

Fall cattle grazing has increased elk use the following spring (Jourdonnais and Bedunah 1990, Frisina 1991). Jourdonnais and Bedunah (1990) recommended that fall cattle grazing be used to make spring forage more attractive for elk. Willms et al. (1979) found that mule deer choose to use fall-grazed areas in the spring. One theory to explain deer and elk preference for areas grazed by cattle in fall by is that fall grazing reduces standing dead material (Willms et al. 1981, Jourdonnais and Bedunah 1985, 1990, Alt et al. 1992). Ungrazed areas accumulate standing dead plant material and stagnant, rank vegetation (Anderson and Scherzinger 1975,
Jourdonnais and Bedunah 1985, 1990). Another theory is that fall cattle grazing increases forb abundance (Stevens 1966). Livestock grazing can increase the amount of forbs for wildlife use (Stevens 1966, found that larger amounts of green growth were present in spring in areas that had been grazed by cattle. However, the effects of fall cattle grazing on deer and elk forage have not been examined in detail. Information on prescribed levels of fall grazing to achieve desired spring and summer forage characteristics is not available. There is a complication of deer and elk preference for areas grazed by livestock in fall. If fall livestock grazing occurs in a rest-rotation grazing system and the fall grazed pasture is rested during the following period of increased deer or elk use, is this increased use due to a change in forage or to the absence of Willms et al. 1979). Willms et al. (1979) domestic livestock and the associated human presence in that pasture?

We hypothesized that larger amounts of green growth, higher forb levels, reduced standing dead material, and/or higher plant diversity are attracting deer and elk to sites previously grazed by cattle. In this study, we describe the impact of fall cattle grazing on spring and summer deer and elk forage. The objectives were to determine if fall cattle grazing improves spring and summer forage for deer and elk, and if so, what grazing intensity is optimum.

\section{Methods}

\section{Study Site}

This study was conducted on the Blackfoot Clearwater Wildlife Management Area (BCWMA), $70 \mathrm{~km}$ northeast of Missoula in west-central Montana $\left(47.0510^{\circ} \mathrm{N}, 113.2726^{\circ} \mathrm{W}\right)$. The Montana Department of Fish, Wildlife, and Parks manages the area for wildlife. Most of the area has been excluded from domestic livestock grazing since 1948 (Baty 1995). Recently, the Montana Department of Fish, Wildlife, and Parks became interested in using cattle grazing as a management tool. Permit grazing was started on portions of the wildlife management area in 1995. Study sites were located on the old Boyd Ranch on the east side of the area. The sites were used by deer and/or elk dur-

Table 2. Effects of forage utilization level in fall on various forage characteristics the following spring and summer.

\begin{tabular}{|c|c|c|c|c|c|c|}
\hline \multirow[b]{2}{*}{ Season } & \multirow[b]{2}{*}{ Forage Variable } & \multirow{2}{*}{$\begin{array}{l}\text { ANOVA } \\
\text { P-value }\end{array}$} & \multicolumn{4}{|c|}{ Treatment Level } \\
\hline & & & $0 \%$ & $50 \%$ & $70 \%$ & $90 \%$ \\
\hline \multirow[t]{3}{*}{ Spring } & $\begin{array}{l}\text { Green herbaceous } \\
\text { standing crop } \\
\left(\mathrm{g} / \mathrm{m}^{2}\right)\end{array}$ & $\mathrm{P}=0.07$ & $88.4 a$ & $75.6 b$ & $78.8 \mathrm{ab}$ & $73.2 b$ \\
\hline & $\begin{array}{l}\text { Green grass } \\
\text { standing crop } \\
\left(\mathrm{g} / \mathrm{m}^{2}\right)\end{array}$ & $\mathrm{P}=0.12$ & 76.0 & 64.0 & 65.6 & 62.4 \\
\hline & $\begin{array}{l}\text { Percent green } \\
\text { vegetation }\end{array}$ & $\mathrm{P}<0.01$ & $49.4 \mathrm{a} 1$ & $82.7 b$ & $92.7 \mathrm{c}$ & $97.7 \mathrm{c}$ \\
\hline \multirow[t]{5}{*}{ Summer } & $\begin{array}{l}\text { Green herbaceous } \\
\text { standing crop } \\
\left(\mathrm{g} / \mathrm{m}^{2}\right)\end{array}$ & $P=0.21$ & 172.4 & 156.4 & 160.4 & 178.8 \\
\hline & $\begin{array}{l}\text { Green forb } \\
\text { standing crop } \\
\left(\mathrm{g} / \mathrm{m}^{2}\right)\end{array}$ & $P=0.83$ & 23.2 & 24.8 & 26.0 & 22.8 \\
\hline & $\begin{array}{l}\text { Percent green } \\
\text { vegetation }\end{array}$ & $\begin{array}{l}19982 \mathrm{P}<0.01 \\
19992 \mathrm{P}<0.01\end{array}$ & $\begin{array}{l}56.1 \mathrm{a} \\
71.2 \mathrm{a}\end{array}$ & $\begin{array}{l}93.7 b \\
94.2 b\end{array}$ & $\begin{array}{l}95.1 \mathrm{bc} \\
99.0 \mathrm{c}\end{array}$ & $\begin{array}{l}98.2 \mathrm{c} \\
99.9 \mathrm{c}\end{array}$ \\
\hline & $\begin{array}{l}\text { Relative abundance } \\
\text { of rough fescue }\end{array}$ & $P=0.97$ & 59.5 & 59.9 & 61.6 & 59.3 \\
\hline & $\begin{array}{l}\text { Plant species } \\
\text { richness }\end{array}$ & $\mathrm{P}=0.57$ & 17.5 & 17.5 & 18.5 & 19.4 \\
\hline
\end{tabular}


ing spring and summer but not in winter.

Climate of the study area is typical of mountainous regions. Annual precipitation varies from 30 to $75 \mathrm{~cm}$ with a mean of 45 cm (Steele 1981). Winter snow accumulations on summer ranges commonly exceed $100 \mathrm{~cm}$ (Baty 1995). Summers are warm and dry; over $66 \%$ of precipitation falls from December to June. Monthly mean temperatures range from $-8.4^{\circ} \mathrm{C}$ in January to $16.8^{\circ} \mathrm{C}$ in July (Steele 1981).

Weather was variable over the 2 years of the study. Total monthly precipitation and average daily temperatures were noticeably different between the 2 years of the study. The second year had a warmer, wetter winter and a cooler, drier spring than year 1 . The cool, dry spring made year 2 a less productive year for vegetation growth.

The study area consists of a mixture of grasslands and forest on gentle mountainous topography. Elevations range from 1,200 to $1,800 \mathrm{~m}$. Grasslands on the study site are dominated by rough fescue (Festuca scabrella Torr.). Additional common species include Idaho fescue (Festuca idahoensis Elmer), Columbian needlegrass (Stipa columbiana Macoun), Richardson's needlegrass (Stipa richardsonii Link), bluebunch wheatgrass (Agropyron spicatum (Pursh) Gould), timber oatgrass (Danthonia intermedia Vasey), prairie junegrass (Koeleria macrantha Ledeb.), threadleaf sedge (Carex filifolia Nutt.), western yarrow (Achillea millefolium L.), sticky geranium (Geranium viscosissimum F. and M.), and lupine (Lupinus spp. Pursh). Several wildlife management areas across western Montana have similar rough fescue dominated range types (Jourdonnais and Bedunah 1985). Rough fescue is considered excellent forage for deer and elk but accumulates dead plant material when grazing is absent (Jourdonnais and Bedunah 1990).

\section{Study Design}

To study the effects of fall cattle grazing on deer and elk forage, we applied different levels of grazing intensity inside enclosures. The experimental unit was a single 20-m x 20-m plot (0.04 ha). Each plot was fenced individually as a separate enclosure for cattle grazing. In 1997 a total of 20 enclosures were constructed in 5 blocks on the east side of the study area. In 1998 the enclosures were torn down and reconstructed on new ground in the same areas. All 10 blocks were constructed on homogeneous sites within the same range site. Blocks were constructed of 3-strand barbed-wire perimeters and divided into individual enclosures with electric fence. Each block contained 1 control enclosure along with 3

Table 3. Botanical composition $(\%, \pm \mathrm{SD})$ of grazing enclosures based on canopy cover.

\begin{tabular}{|c|c|c|c|c|}
\hline \multirow[b]{2}{*}{ Name } & \multicolumn{4}{|c|}{ Treatment Level } \\
\hline & $0 \%$ & $50 \%$ & $70 \%$ & $90 \%$ \\
\hline Graminoids & \multicolumn{4}{|c|}{$\cdots \cdots-\cdots(\%, \pm$ SD) $\cdots \cdots$} \\
\hline Festuca scabrella Torr. & $59.5 \pm 18.9$ & $59.9 \pm 15.4$ & $61.6 \pm 13.9$ & $59.3 \pm 13.4$ \\
\hline Festuca idahoensis Elmer & $6.3 \pm 8.1$ & $4.5 \pm 6.4$ & $3.8 \pm 5.4$ & $4.2 \pm 6.9$ \\
\hline Stipa columbiana Trin. & $1.4 \pm 2.6$ & $3.8 \pm 7.1$ & $2.7 \pm 4.7$ & $0.8 \pm 1.1$ \\
\hline Stipa richardsonii Link & $1.5 \pm 3.2$ & $1.4 \pm 2.9$ & $2.4 \pm 4.6$ & $1.2 \pm 1.6$ \\
\hline Pseudoroegneria spicata (Pursh) A. Love & $1.1 \pm 2.5$ & $0.6 \pm 1.4$ & $0.1 \pm 0.1$ & $0.8 \pm 2.1$ \\
\hline Phleum pratense $\mathrm{L}$. & $0.5 \pm 1.4$ & $0.1 \pm 0.4$ & $0.3 \pm 0.9$ & $0.9 \pm 1.6$ \\
\hline Danthonia intermedia Vasey & $0.6 \pm 0.7$ & $3.4 \pm 3.6$ & $0.9 \pm 1.9$ & $1.2 \pm 1.2$ \\
\hline Koeleria pyramidata Lam. Beauv. & $0.2 \pm 0.3$ & $0.5 \pm 0.6$ & $0.7 \pm 0.7$ & $1.1 \pm 1.4$ \\
\hline Pascopyrum smithii (Rydb.) A. Love & $0.0 \pm 0.0$ & $0.1 \pm 0.3$ & $0.0 \pm 0.1$ & $0.0 \pm 0.0$ \\
\hline Carex spp. & $4.0 \pm 6.5$ & $5.1 \pm 7.8$ & $5.5 \pm 10.7$ & $5.2 \pm 7.9$ \\
\hline Total graminoids & $75.2 \pm 11.6$ & $79.4 \pm 9.5$ & $78.1 \pm 12.0$ & $74.8 \pm 11.7$ \\
\hline \multicolumn{5}{|l|}{ Forbs } \\
\hline Lupinus spp. & $7.5 \pm 5.9$ & $3.8 \pm 4.1$ & $5.0 \pm 5.7$ & $2.8 \pm 4.2$ \\
\hline Achillea millefolium $\mathrm{L}$. & $2.3 \pm 1.9$ & $3.5 \pm 2.0$ & $3.1 \pm 2.6$ & $3.9 \pm 3.1$ \\
\hline Geranium viscosissimum Fisch \& Meyer & $2.7 \pm 5.4$ & $1.0 \pm 1.5$ & $3.0 \pm 5.8$ & $1.9 \pm 3.0$ \\
\hline Antennaria alpina (L.) Gaertn. & $2.9 \pm 3.8$ & $1.9 \pm 3.0$ & $2.0 \pm 2.6$ & $1.6 \pm 2.5$ \\
\hline Erigeron spp. & $1.2 \pm 1.3$ & $1.0 \pm 1.6$ & $1.2 \pm 1.1$ & $1.5 \pm 2.0$ \\
\hline Potentilla gracilis Dougl. ex Hook & $1.1 \pm 1.3$ & $0.6 \pm 0.6$ & $0.4 \pm 0.4$ & $1.3 \pm 1.2$ \\
\hline Hieracium spp. & $0.9 \pm 1.1$ & $0.5 \pm 0.7$ & $0.7 \pm 0.8$ & $0.4 \pm 0.6$ \\
\hline Fragaria spp. & $0.9 \pm 1.0$ & $0.4 \pm 0.3$ & $0.6 \pm 0.6$ & $0.8 \pm 1.0$ \\
\hline Eriogonum spp. & $0.5 \pm 0.5$ & $1.2 \pm 2.3$ & $0.6 \pm 1.0$ & $0.4 \pm 0.6$ \\
\hline Ambrosia artemisiifolia $\mathrm{L}$. & $0.3 \pm 0.6$ & $0.4 \pm 0.8$ & $0.6 \pm 0.7$ & $0.5 \pm 0.7$ \\
\hline Galium spp. & $0.9 \pm 1.5$ & $0.7 \pm 1.5$ & $0.2 \pm 0.5$ & $0.9 \pm 1.4$ \\
\hline Geum triflorum Pursh & $0.1 \pm 0.3$ & $0.1 \pm 0.3$ & $0.2 \pm 0.4$ & $0.4 \pm 0.7$ \\
\hline Tragopogon dubius Scop. & $0.0 \pm 0.0$ & $0.0 \pm 0.0$ & $0.1 \pm 0.3$ & $0.2 \pm 0.6$ \\
\hline Haplopappus armerioides (Nutt.) Gray & $0.3 \pm 1.0$ & $0.3 \pm 0.4$ & $0.1 \pm 0.2$ & $0.2 \pm 0.5$ \\
\hline Penstemon procerus Dougl. ex Grah. & $0.6 \pm 0.7$ & $0.5 \pm 0.8$ & $0.5 \pm 0.8$ & $1.0 \pm 1.3$ \\
\hline Linaria vulgaris Miller & $0.1 \pm 0.2$ & $0.9 \pm 2.7$ & $0.0 \pm 0.0$ & $0.0 \pm 0.0$ \\
\hline Arenaria spp. & $0.1 \pm 0.1$ & $0.4 \pm 0.7$ & $0.3 \pm 0.9$ & $0.7 \pm 2.1$ \\
\hline Zygadenus spp. & $0.0 \pm 0.1$ & $0.1 \pm 0.1$ & $0.1 \pm 0.2$ & $0.1 \pm 0.1$ \\
\hline Artemisia cana Pursh & $0.0 \pm 0.1$ & $0.2 \pm 0.4$ & $0.5 \pm 1.0$ & $0.5 \pm 0.9$ \\
\hline Campanula rotundifolia $\mathrm{L}$. & $0.0 \pm 0.0$ & $0.1 \pm 0.2$ & $0.2 \pm 0.2$ & $0.2 \pm 0.2$ \\
\hline Silene spp. & $0.0 \pm 0.1$ & $0.0 \pm 0.0$ & $0.1 \pm 0.2$ & $0.0 \pm 0.0$ \\
\hline Antennaria pulcherrima (Hook.) Greene & $0.0 \pm 0.0$ & $0.2 \pm 0.5$ & $0.0 \pm 0.0$ & $0.1 \pm 0.2$ \\
\hline Chrysopsis villosa (Pursh) Shinners & $0.0 \pm 0.1$ & $0.1 \pm 0.2$ & $0.0 \pm 0.0$ & $0.4 \pm 1.2$ \\
\hline Descurainia spp. & $0.0 \pm 0.0$ & $0.0 \pm 0.0$ & $0.0 \pm 0.0$ & $0.1 \pm 0.3$ \\
\hline Centaurea maculosa Lam. & $0.1 \pm 0.1$ & $0.0 \pm 0.0$ & $0.0 \pm 0.0$ & $0.0 \pm 0.0$ \\
\hline Annual forbs & $0.6 \pm 0.6$ & $1.2 \pm 1.3$ & $1.1 \pm 0.9$ & $3.8 \pm 4.0$ \\
\hline Other forbs & $1.8 \pm 2.4$ & $1.6 \pm 2.3$ & $1.1 \pm 1.4$ & $1.6 \pm 2.5$ \\
\hline Total forbs & $24.8 \pm 11.6$ & $20.6 \pm 9.5$ & $21.9 \pm 12.0$ & $25.2 \pm 11.7$ \\
\hline \multicolumn{5}{|l|}{ Other } \\
\hline Bare ground & $1.5 \pm 2.1$ & $3.2 \pm 3.6$ & $4.3 \pm 4.3$ & $4.6 \pm 5.2$ \\
\hline Litter & $26.7 \pm 10.1$ & $31.9 \pm 15.0$ & $33.5 \pm 17.1$ & $27.8 \pm 16.3$ \\
\hline Standing dead & $31.7 \pm 11.2 \mathrm{a} 1$ & $2.4 \pm 2.7 b$ & $0.2 \pm 0.4 b$ & $0.0 \pm 0.0 \mathrm{~b}$ \\
\hline
\end{tabular}

${ }^{1}$ Means in the same row followed by different letters are significantly different $(\mathrm{P} \leq 0.10)$.

treatment enclosures. Treatments were randomly assigned within blocks.

\section{Treatments}

During mid September in 1997 and 1998, short duration cattle grazing was implemented on the enclosures in the grazing treatment groups. Eight cow/calf pairs were used for each block. When 1 treatment was completed, cattle were moved to the next treatment within that block. Grazing treatments were monitored so grazing could be terminated when grazing target levels were achieved.

In each block, cattle grazed each of 4 enclosures to $50 \%$ relative utilization, $70 \%, 90 \%$, or $0 \%$ (control). Relative utilization is defined as percent removal of current standing crop as opposed to utilization, which is defined as percent removal of current year's growth. These treatments were equivalent to moderate, heavy, severe, and no grazing (Table 1). A pilot study on the Wildlife Management Area conducted in 1995 and 1996 indicated that relative utilization higher than $50 \%$ was needed to prompt any noticeable change in forage. Relative utilization (Frost et al. 1994) in treatment enclosures was measured by the grazed class method (Kingery et al. 1992). Stubble height measurements were taken along with relative utilization measurements (Table 1). Treatments were all applied within a 2week period. Control enclosures were not grazed by domestic ungulates. 


\section{Vegetation Sampling}

Vegetation data was collected during the spring and summer of 1998 and 1999, according to plant phenology. Spring sampling started 3 weeks after initial green up of rough fescue, which occurred in midMay in 1998 and 5 days later in 1999. Summer vegetation measurements were taken at the seed ripening for the majority of herbaceous species, which occurred in late June in 1998 and 10 days later in 1999.

A double sampling procedure was used to estimate weight of standing crop for spring and summer. Weights of green grass, green forbs, and standing dead material were estimated on a dry matter basis for $15,0.25-\mathrm{m}^{2}$ quadrats in each enclosure. Quadrats were placed every 1 meter along 2 transects. Every fifth quadrat estimated was clipped, bagged, oven dried, and weighed on a dry matter basis for calibration of the estimates. Summer standing crop measurements were taken from the opposite side of transects used for spring collection. Linear regression equations were developed from estimated and actual dry weights of clipped plots with $\mathrm{R}^{2}$ values ranging from 0.72 to 0.97 and averaging 0.84 . The equations were used to calibrate estimated dry weights for green forbs, green grass, and standing dead vegetation.

We used the canopy-coverage method (Daubenmire 1959) to measure plant species composition and relative abundance. Species richness was determined by the average number of species found in enclosures during canopy-coverage sampling. Cover measurements were taken during the summer at seed ripening to facilitate plant identification. Each enclosure had 2 additional $10-\mathrm{m}$ transects for cover sampling. A 20 x 50-cm Daubenmire frame was placed every 0.5 meter on alternating sides along the transects to estimate vegetation canopy cover, totaling 40 frames per enclosure.

\section{Statistical Analysis}

Analysis of variance (ANOVA) general linear model was used to test for differences in forage characteristics (SAS 1998). The initial ANOVA model included year, block, treatment, year*treatment interaction, and block*treatment interaction. Non-significant interactions $(\mathrm{P}>$ 0.10 ) were dropped from the final model, however, all main effects were kept in the final model. Least significant difference (LSD) multiple comparison tests $(\mathrm{P} \leq$ 0.10 ) were used to identify statistical differences among treatment levels if the ANOVA was significant.

\section{Results}

\section{Spring Forage}

Total green herbaceous standing crop in spring was affected by treatment level $(\mathrm{P}=$ $0.07)$. The 50 and $90 \%$ treatments resulted in a reduced amount of green standing crop compared to the control and $70 \%$ treatments (Table 2). Green grass standing crop in spring did not differ among treatment groups $(P=0.12)$. Percent green vegetation in spring was affected by treatment $(\mathrm{P}<$ 0.01 ). Percent green vegetation increased as grazing intensity increased (Table 2).

\section{Summer Forage}

Total green herbaceous standing crop in summer (Table 2) did not differ among treatment groups $(\mathrm{P}=0.21)$. Summer forb standing crop also did not differ $(\mathrm{P}=0.83)$ among treatments. A year*treatment interaction $(\mathrm{P}<0.01)$ existed for percent green vegetation in summer. In 1998, percent green vegetation differed among treatments $(\mathrm{P}<0.01)$. The control treatment averaged $56 \%$ green vegetation and average percent green vegetation increased with increased grazing intensity (Table 2). In 1999, percent green vegetation also differed among treatments $(\mathrm{P}<0.01)$. The control treatment averaged $71 \%$ green vegetation, and average percent green vegetation increased with increased grazing intensity (Table 2).

\section{Species Composition}

Relative abundance did not differ among treatments for rough fescue $(\mathrm{P}=$ 0.97 ) or for any other species (Table 3 ). Relative abundance of rough fescue averaged between $59.3 \%$ and $61.6 \%$ (Table 2). Species richness did not differ among treatments $(\mathrm{P}=0.52)$. The average number of species present in each treatment ranged from 17.5 to 19.4 (Table 2). Standing dead material was the only composition variable that differed among treatments $(\mathrm{P}<0.01)$. The control treatment contained a substantially greater canopycoverage of standing dead material than did the grazed treatments (Table 3 ).

\section{Discussion}

Lower green herbaceous standing crop in the spring as a result of 50 and $90 \%$ treatments is unexplained. The difference was of low significance $(P=0.07)$ and likely does not make a large biological difference. There was no effect of treatment level on green grass standing crop in the spring. Since deer and elk select for green grass during spring, treatment levels had no effect on the production of preferred deer and elk forage. It appears that earlier warming of soil in grazed areas was not beneficial enough to increase spring green herbaceous standing crop. Moisture held by residual plant material could have made up for earlier warming of soil. Our study did not, however, measure timing of spring green-up. It is possible that grazed treatments greened-up earlier, due to quicker soil warming, which would be attractive to deer and elk.

The cause of differences in spring standing crop due to grazing intensity apparently did not affect summer production. McLean and Wikeem (1985) and Willms et al. (1986) also found that fall defoliation did not reduce herbage production the following year.

Higher grazing intensities created higher levels of green vegetation in relation to standing dead material. Our findings agree with those of Willms et al. (1979), in which availability of spring forage was related to degree of prior fall grazing by cattle. Willms et al. (1981) reported that deer did not use areas in spring until new growth extended above standing dead material. When standing dead material is removed, preferred green growth is accessible by deer and elk. In a study of spring forage selection by deer, Willms and McLean (1978) found that forage was only utilized from plants where mature stalks had been removed prior to spring growth.

Our findings on green forb standing crop in summer did not support the theory that deer and elk are attracted to sites grazed by cattle the previous fall due to increased forb levels. To increase forb levels with cattle grazing may take several years of treatments, treatments during the growing season and possibly reduction of rough fescue. Since forbs are the preferred forage for deer and elk in the summer (McMahan 1964, Stevens 1966, Collins et al. 1978, Kasworm et al. 1984, Jourdonnais and Bedunah 1985, Lyon 1985, Canon et al. 1987, Kingery et al. 1996), treatment level did not effect the production of preferred deer and elk forage.

During summer, as in spring, the more intense the utilization treatment the higher the percentage of green vegetation. Deer and elk select for forbs in the summer, but the amount of standing dead material present affects whether forbs are available for consumption by a selective forager. The production of forbs and their availability are both important. Through maintaining forb production and increasing their availability, grazing treatments improved summer forage for deer and elk. 
The lack of differences in the number of plant species present and in the relative abundance of plant species present indicates that we did not alter already healthy range sites. The sites meet goals of providing livestock forage in the fall and preferred deer and elk forage in the spring. A change in the number of plant species present or the relative abundance of plant species present may have reduced the site's ability to meet these goals.

\section{Management Implications}

We improved spring and summer forage for deer and elk on our study site. The reduction of unpalatable standing dead material without compromising forage production is possible with fall cattle grazing. The $70 \%$ utilization treatment would be best for improving forage availability. An average $70 \%$ treatment goal on a landscape level would allow ranges in utilization from 50 to $90 \%$. This would increase percent green biomass in both spring and summer, not reduce green grass standing crop in spring, not reduce green forb standing crop in summer, not alter species richness of the sites, and not alter relative abundance of plant species present. By grazing cattle in the fall, managers can utilize the current year's growth for livestock production and deer and elk forage can be more easily accessed.

Treatment areas should be assessed for use by deer and elk in the winter before treatment. It would be inadvisable to apply fall grazing treatments to an area that is valuable winter range.

McLean and Wikeem (1985) found that heavy fall defoliation of rough fescue did not damage plants. Studies in British Columbia and Alberta found that annual yields of rough fescue were not affected after fall defoliation (McLean and Wikeem 1985, Willms et al. 1986). This suggests that high levels of fall cattle grazing may improve availability of elk and deer forage without damaging or reducing yield of rough fescue plants. However, it is important to monitor the status of rough fescue stands due to their high value for wildlife. McLean and Wikeem (1985) indicated that fall use followed by heavy spring use could damage rough fescue plants. High deer and elk use in the spring could degrade the range and require a change in management. Treated areas should be monitored to determine if the range is being degraded. It is possible that over time, treatments could reduce rough fescue proportional abundance.

Information from this study could be incorporated into rest-rotation or deferred- rotation grazing systems. Pastures recognized as spring and summer range for elk and deer and not winter range, could be grazed to an average of $70 \%$ relative utilization during their fall rotation. This would improve availability of forage in those pastures for deer and elk during the year following treatment.

\section{Literature Cited}

Alt, K.L., M.R. Frisina, and F.J. King. 1992. Coordinated management of elk and cattle, a perspective-Wall Creek Wildlife Management Area. Rangelands 14:12-15

Anderson, W.E. and R.J. Scherzinger. 1975. Improving quality of winter forage for elk by cattle grazing. J. Range Manage. 28:120-125.

Baty, G.R. 1995. Resource partitioning and browse use by sympatric elk, mule deer and white-tailed deer on a winter range in western Montana. M.S. Thesis, Univ. Montana, Missoula, Mont.

Canon, S.K., P.J. Urness, and N.V. DeByle. 1987. Habitat selection, foraging behavior, and dietary nutrition of elk in burned aspen forest. J. Range Manage. 40:433-437.

Clark, P.E., W.C. Krueger, L.D. Bryant, and D.R. Thomas. 1998. Spring defoliation effects on bluebunch wheatgrass: I. Winter forage quality. J. Range Manage. 51:519-525.

Collins, U.J., P.J. Urness, and D.D. Austin. 1978. Elk diets and activities on different lodgepole pine habitat segments. J. Wildl. Manage. 42:799-810.

Daubenmire, R. 1959. A canopy-coverage method of vegetational analysis. Northwest Sci. 33:43-64.

Frisina, M.R. 1991. Elk habitat use within a rest-rotation grazing system. Rangelands. 14:93-96.

Frost, W.E., E.L. Smith, and P.R. Ogden. 1994. Utilization guidelines. Rangelands. 16:256-259.

Jourdonnais, C.S. and D.J. Bedunah. 1985. Improved elk forage: range research along the Sun River. Western Wildl. Spring:20-24.

Jourdonnais, C.S. and D.J. Bedunah. 1990. Prescribed fire and cattle grazing on an elk winter range in Montana. Wildl. Soc. Bull. 18:232-240.

Kasworm, W.F., L.R. Irby, and H.B. Ihsle Pac. 1984. Diets of ungulates using winter ranges in northcentral Montana. J. Range Manage. 37:67-71.

Kingery, J.L., C. Boyd, and P.E. Kingery. 1992. The grazed-class method to estimate forage utilization on transitory forest rangelands. Univ. of Idaho For., Wildl, and Range Exp. Sta. Bull. 54, Moscow, Ida.

Kingery, J.L., J.C. Mosley, and K.C. Bordwell. 1996. Dietary overlap among cattle and cervids in northern Idaho forests. J. Range. Manage. 49:8-15.

Lyon, J.L. 1985. Elk and cattle on the national forests: a simple question of allocation or a complex management problem. Western Wildl. Spring:16-19.
McLean, A. and S. Wikeem. 1985. Rough fescue response to season and intensity of defoliation. J. Range Manage. 38:100-103.

McMahan, C.A. 1964. Comparative food habits of deer and three classes of livestock. J. Wildl. Manage. 28:798-808.

Neal, D.L. 1982. Improvement of Great Basin deer winter range with livestock grazing, $\mathrm{p}$. 61-73. In: J.M. Peek and P.O. Dalke (ed.), Proc. Wildlife-Livestock Ralationships Symp. Univ. of Idaho For., Wildl. and Range Exp. Sta., Moscow, Ida.

Provenza, F.D. and D.F. Balph. 1990. Applicability of five diet-selection models to various foraging challenges ruminants encounter, p. 423-459. In: R.N. Hughes (ed.), Behav. Mech. of Food Selection. Springer-Verlag, Berlin.

Ruyle, G.B., O. Hasson, and R.W. Rice. 1987. The influence of residual stems on biting rates of cattle grazing Eragrostis lehmanniana Nees. Appl. Anim. Behav. Sci. 19:11-17.

SAS. 1998. SAS/STAT user's guide. 7.0 ed. SAS Institute Inc. Cary, N.C.

Steele, R.W. 1981. Weather data summary 1957-1980. Lubrecht Experimental Forest, Greenough, Montana. Mont. Forest and Conserv. Exp. Sta. Misc. Pap. 13. School of Forest., Univ. Montana, Missoula, Mont.

Stevens, D.R. 1966. Range relationships of elk and livestock, Crow Creek drainage, Montana. J. Wildl. Manage. 30:349-363.

Urness, P.J. 1982. Livestock as tools for managing big game winter range in the Intermountain West, p. 20-30. In: J.M. Peek and P.O. Dalke (ed.), Proc. WildlifeLivestock Relationships Symp. Univ. of Idaho Forest., Wildl. and Range Exp. Sta., Moscow, Ida.

Vavra, M. and D. Sheehy. 1996. Improving elk habitat characteristics with livestock grazing. Rangelands 18:182-185.

Wambolt, C.L., M.R. Frisina, K.S. Douglass, and H.W. Sherwood. 1997. Grazing effects on nutritional quality of bluebunch wheatgrass for elk. J. Range Manage. 50:503-506.

Willms, W. and A. McLean. 1978. Spring forage selection by tame mule deer on big sagebrush range, British Columbia. J. Range Manage. 31:192-199.

Willms, W., A.W. Bailey, and A. McLean. 1980. Effect of burning or clipping Agropyron spicatum in the autumn on the spring foraging behaviour of mule deer and cattle. J. Appl. Ecol. 17:69-84.

Willms, W., S. Smoliak, and A.W. Bailey. 1986. Herbage production following litter removal on Alberta native grasslands. J. Range Manage. 39:536-540.

Willms, W., A.W. Bailey, A. McLean, and R. Tucker. 1981. The effects of fall defoliation on the utilization of bluebunch wheatgrass and its influence on the distribution of deer in spring. J. Range Manage. 34:16-18.

Willms, W., A. McLean, R. Tucker, and R. Ritchey. 1979. Interactions between mule deer and cattle on big sagebrush range in British Columbia. J. Range Manage. 32:299-304. 